\title{
Bioprospectors turn their gaze to Canada
}

\section{Rex Dalton, Kelowna}

A Californian bioprospecting company that met resistance to its search for commercially valuable organisms in US national parks is now turning its attention to Canada.

Diversa of San Diego announced its latest plan at the World's Indigenous Peoples conference, held last week in Kelowna in British Columbia, Canada. The conference brought researchers, lawyers and tribal leaders together to discuss the status of intellectual property rights on traditional knowledge.

The company's proposal - believed to be the first of its type in Canada - is to study organisms at paper- or pulp-processing facilities on private land at an undisclosed location. But company officials say they would also like to search public land in Canada.

Government officials say they would welcome this as a starting point for wider exploration, which might lead to the commercial exploitation of either land or knowledge held by Canada's indigenous people.

In 1997, Diversa secured an agreement with the US National Park Service to start bioprospecting at Yellowstone National Park in Wyoming, triggering a still-unresolved dispute over this use of national parks. The Edmonds Institute, a small environmental group based in Washington state, sued the government, successfully calling for an environmental review of the deal, which is due to be completed next summer.

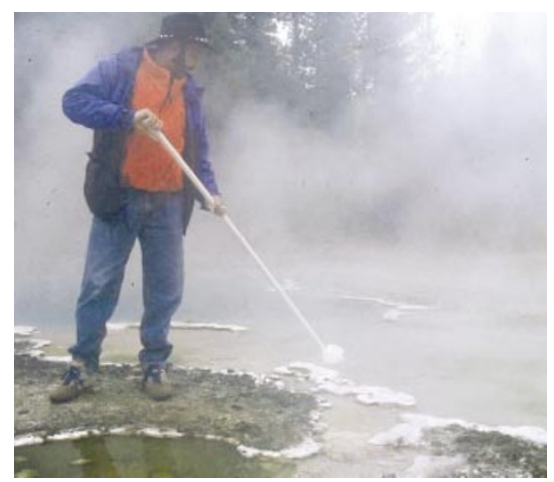

Dip in profits: Diversa's Eric Mathur collecting Yellowstone Park microbes before work stalled.

Diversa's plan to explore in Canada could set the stage for a similar conflict in a nation where suspicion of bioprospecting runs deep, especially among indigenous people. At the Kelowna conference, some speakers described the search for commercially useful natural organisms as "biocolonialism".

Beth Burrows, director of the Edmonds Institute, says she assumes that the Canadian government and public-interest groups "will do all they can to make sure the public is made aware of every step taken, every deal proposed and every agreement made - all in sufficient time for all the public to comment on how their commons are used".

Last month, Diversa officials wrote to the government agency Environment Canada seeking authority to begin bioprospecting.

Jock Langford, senior policy adviser at Environment Canada, says the agency is pleased that Diversa contacted the government before starting work on private land. Government officials are reviewing the matter to see which agency has jurisdiction over lands selected by Diversa, he adds. Indigenous groups might also become involved through their long-standing claims to disputed land, some of their representatives say.

Leif Christoffersen, Diversa's biodiversity coordinator, says that there seems to be no law governing bioprospecting on private land in Canada, but that the status for public land is unclear. "We are interested in exploring public lands, but not until we establish a link with the ministry," says Christoffersen.

Diversa is seeking organisms that might form the basis of a viable biotechnology product. The Taq polymerase enzyme for the polymerase chain reaction, for instance, now used routinely by thousands of researchers, originated from heat-resistant bacteria found at a geyser in the Yellowstone Park.

Diversa has previously cast its net in developing countries, including Costa Rica, Indonesia, Kenya and South Africa. In Mexico, the company retreated after tribes objected to other bioprospectors. Diversa still holds samples from there in a freezer, but says that it is not using them for research.

\section{Marie Curie doesn't live here, Japanese women say}

\section{David Cyranoski, Tokyo}

Japan's female researchers want respect and equal opportunity - without having to meet unreasonable standards of achievement.

That is the prevailing sentiment that arose from the landmark first meeting of a Japanese liaison council for gender equality on 7 October, which brought together 29 academic societies to find ways of improving the status of female researchers in Japan.

Education minister Atsuko Toyama one of four women in the government's 18-member cabinet - opened the meeting, which members hope will mark the start of a serious effort to tackle a long-term problem. The percentage of women scientists tails off into single figures in the upper levels of both industrial labs and universities.

Speakers outlined various ongoing efforts to create a more even playing field, including the introduction of crêches at society meetings and appeals to government, universities and granting agencies to create more transparent evaluation and recruitment systems.
But the meeting heated up when several delegates objected to a mission statement honouring cancer researcher Marie Curie for "having proven the outstanding ability of women in the natural sciences". "The statement implies that only special women with tremendous abilities can compete with men," said Kay Domen, a researcher on blue semiconductor lasers at Fujitsu Quantum Devices. "Regular women also need to be able to compete." It is now being revised.

The committee's first task is to conduct a nationwide survey. One of the organizers, Kazuo Kitahara, president of the Physical Society of Japan, says she is confident that the committee will get a grant from the education ministry to collect statistics on the number of women in different fields, their success in obtaining grants, and even information about the prevalence of sexual harassment. Female researchers say that a lack of detailed information has exacerbated their problems (see Nature 410, 404-406).

Despite some scepticism from meeting participants about its chances of making a difference, the committee has at least raised awareness. For example, the Society of Chemical Engineers, Japan, now recognizes that only $2 \%$ of its members are female - and none of these women holds a senior position in industry or academia. "Until now we had never thought about building a society based on equal participation by men and women," the society admitted in a statement.

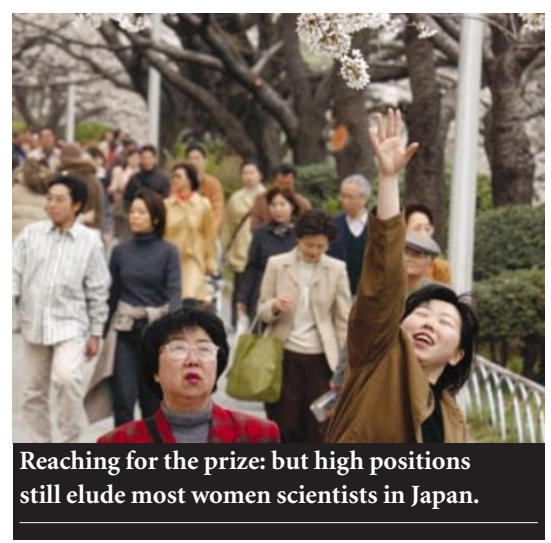

